\title{
Editorial
}

\section{Endoscopy in Extraesophageal Manifestations Secondary to Gastroesophageal Reflux Disease: Why Do We Insist?}

\author{
Cláudia Macedo ${ }^{\mathrm{a}}$ Nuno Almeida ${ }^{\mathrm{a}, \mathrm{b}}$ \\ a Department of Gastroenterology, Centro Hospitalar e Universitário de Coimbra, Coimbra, Portugal; \\ ${ }^{b}$ Faculty of Medicine, University of Coimbra, Coimbra, Portugal
}

\section{Keywords}

Upper gastrointestinal endoscopy · Gastroesophageal reflux disease $\cdot$ Extraesophageal manifestations

\section{Endoscopia Nas Manifestações Extra-Esofágicas Secundárias à Doença do Refluxo Gastro-Eesofágico: Porque Razão Insistimos?}

\section{Palavras Chave}

Endoscopia digestiva alta . Doença do refluxo gastroesofágico · Manifestações extra-esofágicas

The concept of extraesophageal manifestations secondary to gastroesophageal reflux disease (GERD) is complex and not always clear. Although several extraesophageal symptoms have been associated with GERD, only asthma, cough, and hoarseness have evidence-based support [1]. The role of upper gastrointestinal endoscopy (UGIE) in GERD is that of screening in certain high-risk groups in particular overweight white males with chronic GERD symptoms and aged $>50$ years [2]. In the context

\section{KARGER}

karger@karger.com www.karger.com/pjg
(C) 2020 Sociedade Portuguesa de Gastrenterologia Published by S. Karger AG, Basel

Karger

Upen access

This article is licensed under the Creative Commons AttributionNonCommercial-NoDerivatives 4.0 International License (CC BYNC-ND) (http://www.karger.com/Services/OpenAccessLicense). Usage and distribution for commercial purposes as well as any distribution of modified material requires written permission. of suspected extraesophageal manifestations of GERD, UGIE has a low diagnostic yield and therefore poor predictive value for determination of GERD as the cause of these symptoms [1]. However, despite the foregoing, UGIE is still frequently requested and little is known about endoscopic findings in this context.

In this issue of GE Portuguese Journal of Gastroenterology, Zullo et al. [3] present us the first study with data on the prevalence of relevant gastroesophageal lesions in patients with extraesophageal GERD manifestations. The authors concluded that clinically relevant lesions namely Barrett's esophagus, erosive esophagitis, and hiatal hernia are uncommon among young ( $<50$ years) patients with only extraesophageal GERD manifestations, and the usefulness of UGIE in these patients is questionable.

One of the major factors that contributes to the controversy of GERD-associated extraesophageal manifestations is that other potential causes have not been adequately evaluated and/or treated before [4]. In Zullo et al. [3], UGIE was prescribed by different specialists and nothing was told about other previous tests done in investigation and its results. Additionally, the specificities about present or past proton pump inhibitors therapy (dosage, duration, response) have not been given. On the 
other hand, the authors included patients with alarm symptoms who have formal indication for UGIE and a higher pre-test probability of having relevant endoscopic findings. With this in mind, we think that perhaps the endoscopic findings in patients with true extraesophageal GERD manifestations may be even less prevalent. Other study limitations, highlighted by the authors, were the relatively small number of patients with only atypical GERD symptoms and the sample size. Nonetheless, the authors bring us a relevant topic reinforcing the low diagnostic yield and clinical impact of UGIE in patients with only extraesophageal manifestations, especially in the youngest and those without alarm symptoms.

Considering the negative impact that inappropriate UGIEs have on resources utilization as well as the medico-legal issues that are already a concern, we would like to congratulate the authors for the criticism shown re- garding the prescription of UGIE in suspected extraesophageal manifestations of GERD, contributing to the creation of evidence which reinforces this position.

\section{Disclosure Statement}

The authors have no conflicts of interest to declare.

Funding Sources

No funding was received.

\section{Author Contributions}

Both authors contribute to all stages of editorial composition.

\section{References}

1 Vaezi MF, Katzka D, Zerbib F. Extraesophageal Symptoms and Diseases Attributed to GERD: Where is the Pendulum Swinging Now? Clin Gastroenterol Hepatol. 2018 Jul; 16(7):1018-29.

2 Katz PO, Gerson LB, Vela MF. Guidelines for the diagnosis and management of gastroesophageal reflux disease. Am J Gastroenterol. 2013 Mar;108(3):308-28.
3 Zullo A, Fiorini G, Bassotti G, Bachetti F, Monica F, Macor D, et al. Upper endoscopy in patients with extra-oesophageal reflux symptoms: a multicenter study. GE Port J Gastroenterol. 2020:1-6, DOI: 10.1159/000505581.
4 Vaezi MF, Hagaman DD, Slaughter JC, Tanner SB, Duncavage JA, Allocco CT, et al. Proton pump inhibitor therapy improves symptoms in postnasal drainage. Gastroenterology. 2010 Dec;139(6):1887-1893.e1. 